\title{
Klaus Bochmann, Lexicul social-politic român între 1821 și 1848. Traducere de Octavian Nicolae, Editura Universităţii „Alexandru Ioan Cuza”, Iași, 2017, 313 p.
}

\author{
Mihaela Mocanu* \\ Departamentul de Cercetare Interdisciplinar - Domeniul Socio-Uman, Universitatea „Alexandru Ioan Cuza”, \\ Str. Lascăr Catargi 54, 700107 Iași, România
}

Spre deosebire de alte terminologii, lexicul politic manifestă un grad mai mare de permeabilitate față de unitățile vocabularului comun, care nu solicită eforturi deosebite în procesul de receptare. În demersul de conceptualizare, vizînd descrierea și explicarea fenomenelor din viața politică, limbajul politic recurge atît la termeni specifici (partid, formațiune politică, senat, parlament, guvern, prezidențial, electoral etc.), cît și la elemente ale vocabularului comun, pe care le îmbogățește cu semnificații noi (dreapta, stînga, centru, roșu, portocaliu). Fenomenul circulației este bilateral, o serie de termeni specifici domeniului politic pătrunzînd, la rîndul lor, în limbajul colocvial. În aceste condiții, delimitarea cu strictețe a unui inventar lexical specific comunicării social-politice se dovedește o întreprindere dificilă, întrucît diferențele dintre lexicul social-politic și vocabularul comun nu rezidă atît în cuvintele utilizate, cît în funcțiile pe care acestea le îndeplinesc, în actul comunicării socialpolitice (Denquin, 2007, p. 22).

Apărută la Editura Universităţii „Alexandru Ioan Cuza” Iași, în 2017, în traducerea lui Octavian Nicolae, cartea lui Klaus Bochmann Lexicul socialpolitic român între 1821 și 1848 mărturisește încă din capitolul introductiv ambiţia de a oferi o istorie a conceptelor social-politice românești din prima jumătate a veacului al XIX-lea. Lucrarea își are originile în teza de abilitare a autorului, susținută la Facultatea de Litere a Universității din Leipzig, în 1976, și poartă amprenta teoriilor lingvistice și a direcțiilor metodologice manifeste în epocă. Proiectul se dovedește unul de anvergură cu atît mai mult cu cît, delimitarea inventarului terminologic aferent domeniului social-politic se realizează pe baza unui registru bogat și variat de surse: literatură politică, publicistică, notații personale, corespondență oficială și privată, memorii cu conţinut politic, dar și documente oficiale.

Pornind de la premisa că: „Orice eveniment istoric de mare importanță se răsfrînge în mod nemijlocit asupra lexicului social-politic al limbii poporului respectiv. Orice practică socială nouă produce noțiuni noi, cuvinte noi, face ca termeni ancorați în tradiție să dispară sau să primească sensuri noi" (Bochmann, 1970), autorul întreprinde un demers de inventariere a lexicului social-politic românesc din prima jumătate a secolului al XIX-lea, prin raportare la evenimentele politice, economice și sociale din epocă. Pe lîngă apariţia unor termeni noi, aferenți domeniului social-politic, autorul este interesat de modificările semantice pe care le suferă aceștia în perspectivă diacronică. Analiza semantică este complinită de abordarea sociolingvistică generată de necesitatea raportării inventarului terminologic la modificările pe care le înregistrează realitățile socialpolitice românești. În acest sens, autorul distinge trei etape în procesul de constituire a lexicului socialpolitic românesc: a.1780/1800-1820: etapa de incubație; b. 1821-1848: etapa maturizării rapide c. 1848/49-1850: etapa dezvoltării și consolidării noului cod terminologic.

Organizîndu-și materialul în șase capitole prefațate de o secțiune dedicată obiectului și metodelor cercetării, Bochmann își structurează prezentarea într-o manieră diacronică: 1. Preistoria vocabularului social-politic român modern; 2. Vocabularul social-politic în perioada 1800-1820; 3. Evoluțiile lexicale între 1821 și 1829; 3. Evoluțiile lexicale între 1821 și 1829; 4. Primul deceniu al Regulamentului Organic (1830-1839); 5. De la „Dacia literară” la revoluția de la 1848/49; 6. Observații finale. Lexicul social-politic este cercetat în tăieturi sincronice, pentru fiecare deceniu, începînd cu 1821, fiind prezentate conceptele-cheie, evenimentele istorice și

*Adresă de corespondență: mihaelamocanuiasi@yahoo.com. 
personalitățile care au influențat constituirea noilor cîmpuri de semnificații.

Autorul inițiază demersul descriptiv cu secolul al XIV-lea, considerat matricea lexicului social-politic românesc. Apariția terminologiei social-politice este pusă în legătură cu istoria relațiilor social-culturale interne şi a raporturilor cu popoarele vecine, fiind modelată de factori precum: moștenirea latină, conviețuirea slavo-română, cultura ortodoxă, dominația maghiară și poloneză, raporturile ierarhice de dominație din sistemul feudal. Lexicul social-politic al limbii române vechi cuprinde un inventar relativ limitat de cuvinte moștenite din latină, îmbogățit cu formații românești, un procent consistent de elemente din slavona bisericească și, în mică măsură, din elemente maghiare, ucrainene și rusești, expresie a influenței culturale și politice a vecinilor asupra societății feudale românești. La acestea se adaugă în sec. al XVII-lea și, cu precădere, în sec. al XVIII-lea elemente din neogreacă și turcă. Dimitrie Cantemir este considerat un precursor al vocabularului politico-social modern, autorul Istoriei ieroglifice construindu-și discursul în jurul a trei conceptecheie: monarchie, dimocratie și (re)publică, care sintetizează viziunea sa politică (p. 31-39).

Perioada 1800-1820, descrisă în cel de-al doilea capitol al cărții, stă sub semnul activității Școlii Ardelene și al eforturilor acesteia de a susține cu argumente istorice și filologice drepturile românilor. Luminare, cultură și polire sînt, în viziunea lui Bochmann, conceptele care rezumă ideile promovate de reprezentanții iluminismului: conștiința măreției istorice, năzuința spre emancipare națională și voința de unitate națională. Denumirile pentru noile concepte politice sînt, de regulă, împrumuturi: nație, cultură, educație, toleranție, superstiție, libertate, dar lexicul acestei perioade relevă și extinderi ale semnificației termenilor tradiționali (neam cu sensul de 'nație'). Subordonarea administrativă diferită şi situaţia social-culturală distinctă din Principate a condus la diferenţieri ale lexicului social-politic în aceste regiuni: „Dacă vocabularul învățaților transilvăneni corespunzător surselor lor ideologice și ideilor lor filologice este împănat cu neologisme latinoromanice, cel al scriitorilor moldoveni şi munteni prezintă mai multe calcuri, preferate, ca mai ușor de înțeles, și de unii ardeleni, sau împrumuturi din greacă” (p. 62). Neologismele latino-romanice se vor impune abia în deceniile următoare în Moldova și
Ţara Românească.

Începînd cu 1821 centrul de greutate al evoluției socio-culturale a românilor se mută din Transilvania în Țara Românească. Capitolul 3, Evoluțiile lexicale intre 1821 şi 1829, evidențiază cel mai mare cîștig al acestui deceniu: constituirea unei opinii publice românești. Conștiința existenței unei opinii publice se exprimă, printre altele, în încercarea de a o fixa terminologic, prin termeni precum obște, public sau politie. Vocabularul administrației de stat se caracterizează acum prin coexistența elementelor tradiționale românești cu cele moderne de origine latinoromanică, dar și cu elemente turcești, grecești și rusești. Influența latino-romanică în lexicul administrativ continuă să rămînă destul de redusă. Revoluția lui Tudor Valdimirescu, de la 1821, va determina evoluții semantice ale termenilor tradiționali: astfel, lexeme precum norod, boieri și patrie dobîndesc valențe semantice noi, care nu existau în istoria limbii române de pînă atunci. Introducerea de neologisme, preponderent din domeniul filosofiei sociale şi al teoriei statului, este contribuția literaturii politice din perioada 1825-1829 la dezvoltarea lexicului politic. Conceptele referitoare la organizarea statală cunosc o îmbogățire semantică și o creștere considerabilă. Un rol important în apariţia lexicului socialpolitic românesc îl joacă, începînd cu 1829, ziarele „Curierul Românesc” și „Albina Românească”.

Deceniul 1830-1839 stă sub semnul Regulamentului Organic. Redactat în 1830 și adoptat în 1831 în Muntenia și în 1832 în Moldova, documentul stipula reglementări privind separarea puterilor, existența unei Adunări Obștești și introducerea consiliilor orășenești alese. Cele mai vizibile schimbări ale vocabularului politico-administrativ din deceniul al patrulea se datorează modernizării radicale a administraţiei din Principate. Raportul dintre fondul tradiţional de cuvinte și terminologia modernă evidențiază caracterul tranzitoriu al conținutului şi limbajului Regulamentului. Remarcabil pentru schimbările politice intervenite de la sfîrşitul epocii fanariote este numărul mic de elemente grecești și turcești din Regulament. Termenii turcești vizează, de regulă, denumiri ale gradelor din armată și poliție şi diferite dări către Poartă. Persistența formulelor și expresiilor tradiționale în condițiile statului modernizat reiese din supraviețuirea unor termeni ca jalobă, obraze, pitac, hrisov ș.a. În ciuda caracterului eterogen al lexicului din această perioadă, tendința 
spre împrumuturi latino-romanice devine evidentă, pregătind unitatea ce avea să se realizeze în a doua jumătate a secolului al XIX-lea.

Interesantă este evoluția semantică pe care o înregistrează în deceniul al patrulea termenul nație: „Nație este folosit pentru a desemna națiunea română în totalitatea ei, or, în deceniul anterior ea desemna de cele mai multe ori doar părți ale poporului român” (p. 123). Printre atributele nației, contemporanii așează trăsăturile lingvistice, culturale și istorice comune. Paralel cu nație continuă să circule sinonimul neam. Tot în acest deceniu al patrulea, cuvîntul $R o$ mânia, folosit multă vreme ca sinonim pentru Țara Românească, începe să desemneze întregul teritoriu românesc. Ortografierea oscilează între Rumânia și România.

Anii patruzeci ai secolului al XIX-lea constituie, potrivit autorului, deceniul hotărîtor pentru formarea vocabularului social-politic modern. Capitolul 5, De la Dacia literară la Revoluția de la 1848/1849, surprinde principalele caracteristici ale perioadei: ideologia pașoptistă își găsește acum expresia lexicală într-un vocabular relativ uniform, iar utilizarea lexicului social-politic nu mai este apanajul exclusiv al intelectualilor. Se observă o relativă nivelare a diferențelor semantice, mai puțin a celor morfologice și ortografice, în utilizarea lexicului social-politic. „Uniformitatea relativă a termenilor din textele scrise, democratizarea lor prin pătrunderea în popor și o oarecare variație de sens și formală, în funcție de nivelul de instrucție, acestea sînt trăsăturile care caracterizează situația comunicativă din jurul anului 1848” (p. 145). Deschiderea spre împrumuturi, în special din limbile romanice, devin tot mai evidente în acest deceniu. Tentaţia pentru neologism, motivată de unii cercetători prin rapiditate și comoditate (Pană Dindelegan, 1997), devine o constantă a mijlocului de deceniu, pregătind saltul calitativ din cea de-a doua jumătate a secolului. Probleme ridică însă determinarea originii împrumuturilor, care reprezintă cea mai mare pondere a lexicului din anii '40. Dacă în cazul limbii-sursă, lucrurile sînt clare-franceza, constituind sursa predilectănu acelaşi lucru se poate spune despre autorii sau curentele de la care se împrumută termenii.

Procesul formării lexicului social-politic modern ajunge, odată cu revoluția din 1848/1849, la o treaptă de dezvoltare care relevă sincronizarea culturii românești și a gîndirii social-politice cu cele mai înaintate culturi din Europa. Printre trăsăturile lexicului acestei perioade, Klaus Bochmann notează: persistența unei puternice influențe rusești, dispariția treptată a elementelor din turcă și neogreacă, sporirea influenţei latino-romanice și păstrarea denumirilor tradiţionale, îndeosebi pentru autorități și titluri oficiale. Conceptele-cheie ale filosofiei sociale în această perioadă sînt progres, civilizație și societate. În contextul revoluției, noțiunea de popor suferă modificări semantice și formale importante: folosit rar în sens social-politic pînă acum, popor (cu variantele popol și popul) începe să înlocuiască termenul norod. Analiza evoluției semantice a termenului oferă prilejul unor observații de ordin sociolingvistic: „faptul că norod continuă să fie folosit ni se pare simptomatic pentru un anumit conservatorism lingvistic în Moldova, avîndu-și rădăcinile în situația istorică concretă și în slăbiciunea forțelor antifeudale” (p. 189).

Printre cuvintele-slogan ale revoluției de la 1848 se află dreptate, frăție. Documentele guvernului provizoriu, paginile de publicistică, corespondența particulară a revoluționarilor cuprind această deviză, a cărei circulație se limitează la Țara Românească. În Transilvania, aflăm la 1848 o reformulare a lozincii Revoluției Franceze de la 1789: libertate, egalitate, fraternitate. Autorul subliniază lipsa de precizie semantică a termenilor cuprinşi în aceste devize, polisemia fiind favorizată și de gradul de circulație a acestora (Bidu-Vrănceanu, 2007). Preferința pentru formele vechi slobozenie, respectiv potrivire este modelată de încadrarea ideologică a utilizatorilor, fiind mai des întîlnite în limbajul conservatorilor, în vreme ce libertate și egalitate devin apanajul forțelor progresiste.

Problema unităţii naționale și a independenței, cea mai importantă chestiune în istoria României de la jumătatea secolului al XIX-lea, își găsește expresia în multitudinea și frecvența cuvintelor-cheie din aria semantică națiune. În prim plan stau denumirile nație și naționalitate, ultima, relativ nouă, cîștigînd teren în detrimentul lui nație. În comparație cu semantica relativ mai clară a termenului nație, naționalitate prezintă caracterul difuz caracteristic cuvintelor-slogan. În Transilvania, unde se pune problema de a se asigura românilor aceleași drepturi ca și celorlalte popoare, naționalitate apare frecvent cu sensul de „dreptul la existență națională”.

Între 1840 și 1850 literatura social-politică românească şi lexicul aferent se dezvoltă în mod exploziv, 
în contextul unei producții considerabile de cărți și de periodice. Potrivit lui Klaus Bochmann, limba română modernă își elaborează lexicul politico-social în linii generale pînă la jumătatea secolului al XIXlea. Vocabularul politicii și al domeniilor învecinate este dominat, începînd cu deceniul al cincilea, de împrumuturi, aproape exclusiv din franceză. Acestea înlocuiesc nu numai elementele din neogreacă, turcă şi rusă, ci și formele tradiţionale provenite din limba veche sau create în primele decenii ale secolului al XIX-lea (norod, slobozenie, inaintare, propăşire etc.). Autorul atrage atenția asupra diferențelor care vizează ritmul și calitatea modernizării lexicului în diferitele compartimente ale lexicului politico-social (administrație, economie, politică, relații sociale ș.a.). Astfel, în administraţie se mențin încă elemente tradiţionale şi de origine slavonă, iar în domeniul comerțului circulă în continuare termeni turcești și grecești.

Deceniul al cincilea marchează o relativă încheiere a procesului de formare a lexicului socialpolitic românesc. Contradicția dintre lexicul cu influențe grecești, turcești și rusești, din Principatele Dunărene, și cel latinizant, din Transilvania, care a durat pînă în primele decenii ale secolului al XIXlea, este depăşită în anii ' 40 . Tendințele latinizante ale mişcării naționale din Transilvania nu periclitează omogenitatea relativă a lexicului politico-social românesc. Deosebirile dintre cele trei regiuni românești rămîn, spune Bochmann, neînsemnate, acest lucru fiind favorizat de schimbul intens de idei dintre intelectualii din aceste regiuni.
Observațiile finale ale cărții sînt organizate în două secțiuni: 1. Istoria limbii române literare și a lexicului politico-social modern și 2. Relația dintre limbă și societate. Lucrarea este însoțită de trei anexe: 1. Lista documentelor citate și siglele lor; 2. Indice de nume și 3. Indice de termeni, care oferă o imagine de ansamblu, atît asupra surselor documentare, cît și asupra lexicului inventariat de autor.

Meritul lucrării lui Klaus Bochmann constă în radiografierea unei perioade mai puțin cercetate din istoria terminologiei social-politice la noi. Autorul acordă o pondere însemnată abordării semantice, în condițiile în care procesul de modernizare a lexicului social-politic nu constă doar în înlocuirea unităților lexicale mai vechi (provenite din slavă, turcă, neogreacă) cu altele noi (din franceză, italiană, latină), ci, mai ales, în atribuirea de valențe semantice noi elementelor lexicale existente în uz. Complinind și susținînd analiza semantică, abordarea sociolingvistică a inventarului lexical a avut în vedere aspecte precum: regiunea din care provin vorbitorii (Transilvania, Moldova, Țara Românească); apartenența la clase, pături sociale şi orientări ideologice particulare; gradul de instrucție al vorbitorilor; așteptările vorbitorului în legătură cu nivelul social și cultural al publicului său; codul și mijloacele lingvistice de care dispune epoca; natura canalului de comunicare: scrisoare, articol de ziar, proclamație etc. Concepută în 1976, lucrarea rămîne un titlu de referință în literatura de specialitate dedicată terminologiei socialpolitice românești.

\section{Bibliografie}

Bidu-Vrănceanu, A. (2007). Lexic specializat în mișcare de la dicționare la texte, Editura Universității din București.

Bochmann, K. (1970). Dezvoltarea vocabularului social-politic român între 1840-1850, în Actele celui de-al XII-lea congres internațional de lingvistică și filologie romanică, Editura Academiei, București, p. 869-873.

Denquin, J.-M. (2007). La politique et le langage, Michel Houdiard Éditeur, Paris.

Pană Dindelegan, G. (1997). Terminologia lingvistică actuală, între tradiție și inovație, în „Limbă și Literatură”, nr. 3-4, p. 6. 